\title{
The Role of Facilitating Conditions and User Habits: A Case of Indonesian Online Learning Platform*
}

\author{
Rita AMBARWATI ${ }^{1}$, Yuda Dian HARJA ${ }^{2}$, Suyono THAMRIN ${ }^{3}$
}

Received: July 25, 2020 Revised: August 23, 2020 Accepted: August 28, 2020

\begin{abstract}
The study examines the role of facilitating conditions and user habits in the use of technology in Online Learning Platform (OLP) in Indonesia. The adoption of online learning, persistence, and learning results in online platforms is essential for ensuring that education technology is implemented and gets as much value as possible. People who use technology and systems will embrace new technologies even more. This quantitative study is based on a survey of 254 respondents, who were active users of the technology, and considers the facilitating conditions and user habits variables. Two research hypotheses were tested using the Partial Least Square-Structural Equation Modeling method. Cronbach's Alpha, path coefficient, AVE, R-square, T-test were applied. The results showed that the factors significantly influence the Online Learning Platform technology behavioral intention. This impact is primarily associated with the availability of the resources required to use OLP technology. The availability of these resources includes supporting infrastructures such as widespread Internet access, easy access to mobile devices, and file sizes that affect access speed. The findings of this study suggest that it is necessary to introduce and increase the availability of resources for using OLP technology, and familiarize people with the technology features.
\end{abstract}

Keywords: Facilitating Conditions, Online Learning Platform, Technology Utilization, User Habits

JEL Classification Code: I24, P36, P46

\section{Introduction}

Online learning has experienced very significant development in recent years, and this is no longer the sole domain of teachers. Online learning solves the problem of time flexibility because it does not bind the users to a particular time. However, not all regions have supporting facilities available to conduct online learning (Ain et al.,

\footnotetext{
*Acknowledgements:

The authors acknowledge grants and the financial support of the Ministry of Research, Technology, and Higher Education of the Republic of Indonesia in Postgraduate Grants.

${ }^{1}$ First Author and Corresponding Author. Assistant Professor, Faculty of Business Law and Social Science, Universitas Muhammadiyah Sidoarjo, Indonesia [Postal Address: Majapahit 666B, Sidoarjo, East Java, 61215, Indonesia] Email: ritaambarwati@umsida.ac.id ${ }^{2}$ Department of Management Technology, Institut Teknologi Sepuluh Nopember, Indonesia. Email: yudaharja@gmail.com

${ }^{3}$ Assistant Professor, Faculty of Defense Management, Universitas

Pertahanan, Indonesia. Email: suyono.thamrin@idu.ac.id

(c) Copyright: The Author(s)

This is an Open Access article distributed under the terms of the Creative Commons Attribution Non-Commercial License (https://creativecommons.org/licenses/by-nc/4.0/) which permits unrestricted non-commercial use, distribution, and reproduction in any medium, provided the original work is properly cited.
}

2016). The condition of limited human resources also causes relatively high inequality (Ambarwati et al., 2020). Changes and demands of the times are very fast, creating a gap in the field of information and communication technology (Broadbent \& Poon, 2015). This gap has become one of the problems of how the broader community can accept technology. Developments and improvements in technology have transformed various businesses in operating industries, including the government.

The complexity in digital information affects the management, processing, storage, security, and disposal of information. New tools for collecting, searching, and analyzing organizations help businesses gain insights from their unstructured data. These technologies become essential tools to overcome the complexity of increased digital information in the long term (Lee, 2020).

Indonesian online education cannot escape from problems such as, firstly, the lack of stakeholder and management support in implementing online learning. This obstacle usually exists in institutions that are not yet fully aware of the potential and opportunities for the use of online learning to support the learning process nowadays (El Ouirdi et al., 2016; Lieharyani et al., 2019). Secondly, the infrastructure 
in some areas is not yet ready for the optimal application of online learning (Muniasamy \& Alasiry, 2020). However, the infrastructure is a fundamental factor in implementing online learning, like a banking system where transactions must be available 24 hours a day, seven days a week (ElMasri \& Tarhini, 2017). Thirdly, utilization of facilities in Learning Management Systems (LMS) for the learning process is minimal. Usage is still limited to learning material repositories, and there are not many interactive features between instructors and students (Al-Husban \& Alshorman, 2020). The use of online learning systems in Indonesia has begun to move from merely utilizing LMS and other ICTbased tools. An in-depth review process is needed to examine the implications of online learning systems for learning achievement and teaching effectiveness (Gupta et al., 2016).

Studies on online learning state that understanding the adoption of online learning, continuation, and learning outcomes via online platforms are fundamental in ensuring that technology in education has been implemented and gets the maximum benefit (Panigrahi et al., 2018). The same conclusion also suggests that information technology plays a central role in teaching at the university. A broad introduction to technology-based education requires fundamental changes to institutions to meet the needs of students and society (Santoso et al., 2019) A previous study on student demographics from a Massive Open Online Course (MOOC) examined online learning platform Coursera. The research showed that $29.5 \%$ of students are 18-25 years old, and $30.3 \%$ are $26-34$ years old (Jalil et al., 2019; Engle et al., 2015). One of the OLP technology providers in Indonesia, Ruang Guru, had more than 6 million users by the end of 2017. A large number of users of Ruang Guru proves that Indonesia already has enough OLP users (Santoso et al., 2019) The adoption of technologies such as online learning in educational systems is questioned, including funding, expertise, and ability (Gallego \& Topaloglu, 2019). The online learning system introduces four different categories of challenges in developing countries - challenges to students and teachers, technology challenges, course challenges, and contextual challenges. Online learning problems also remain in learning institutions in terms of access, pedagogy, expertise, and training and equipment inequalities (Santoso et al., 2019).

Based on previous studies, this research focuses on the influence of variables facilitating conditions and user habits on OLP behavior intentions in Indonesia. Since 1970, information and communication technology in the country has developed rapidly. This development continues to run gradually, including in the business and education environment. Indonesia has implemented online learning for the learning process (Santoso et al., 2019). That is because there are many benefits found in online learning content that can be accessed anytime and anywhere. Everyone can use this facility by not having to spend a lot of time coming to a place of learning. Besides, online learning is also beneficial for a company because it saves time and money to train its employees (Niemi \& Jia, 2017). The following subsections present the company's strategic orientation depending on what it wants to achieve. Companies with strong customer focus will emphasize establishing and maintaining its customer value. It will be different if the companies focus more on their competitors because they will take the targeted competitors to a thorough assessment (Muafi, 2020). The online learning is helpful from various angles in a company, namely, anywhere, anytime, any space as long as the existence of the Internet network supports it (Swan et al., 2019). Besides, online learning content is beneficial to large companies that have many branches (Xiang et al., 2015). The management does not need to bother going to every office of the company because online learning can reach all branches of the company for training activities (Nguyen, 2015).

\subsection{Facilitating Conditions}

Facilitating conditions refer to the degree to which a person believes that the existing organizational and technical infrastructure can support the use of technology (Chan et al., 2010). In his study, Venkatesh stated that facilitating conditions do not affect behavioral intention, but affect use behavior. Facilitating conditions are related to the availability of sufficient resources and support for individuals to use technology (Neslin \& Shankar, 2009). Lack of assistance, lack of timely support, incomplete information, and limited resources can prevent individuals from accepting web-based technology (Kamaghe et al., 2020). Internet connectivity and social networking sites have seen tremendous development in all regions of the world. Social networking sites change the way people communicate worldwide quickly. They increase electronic communication to almost face-to-face methods by one of the most popular connected devices people today use - mobile phones (Lee, 2017).

There is a tendency that older consumers face more difficulties in responding to new and complex information, so that it affects their learning process of new technology (Halili \& Sulaiman, 2019; Paul et al., 2015). Conditions related to this difficulty can be associated with a decrease in cognitive abilities and memories related to the aging process (Liu et al., 2015). Therefore, when compared with younger consumers, older consumers tend to prioritize the availability of adequate support (Pimmer et al., 2019).

On the other hand, when compared to women, men are willing to make more effort to overcome various obstacles and difficulties in pursuing their goals. In contrast, women tend to focus more on the amount of effort involved and the process to achieve their goals (Venkatesh et al., 2005). Thus, it can be concluded that men tend not to depend on facilitating conditions when they consider using new technology. In contrast, women have a tendency to put more emphasis on 
external supporting factors. More experience can lead to greater familiarity with technology and better knowledge to facilitate learning, thereby reducing dependence on external support (Kamaghe et al., 2020; Masadeh et al., 2016). People's views of technological developments in the context of the relationship between the industrial revolution and environment have changed from negative to positive. Besides, high-level technology generated data that can be used for optimizing the production of goods, economic development, and corporate networking (Choi et al., 2019). Users with little technological experience will be more dependent on facilitating conditions (Paul et al., 2015).

According to Venkatesh et al. (2012), the facilitating conditions have four indicators, namely, the resources/ facilities to use OLP technology, the knowledge of OLP technology usage, OLP technology compatibility with other techniques used, and the availability to get help from others when having difficulty using OLP technology (Figure 1).

H1: Facilitating conditions have a significant influence on behavioral intentions to use online learning.

\subsection{User Habits}

User habits refer to the extent to which individuals tend to adopt behavior automatically because they have learned before. In the context of consumers, habits play an essential role in the use of technology, especially in a diverse and continually-changing situation (Perrin et al., 2011; Venkatesh et al., 2012). User habits relate to individual practices or automatic behavior using technology. User habits construct perception that reflects the results of previous experiences. User habits relate knowledge, age, and gender to behavioral intention and use behavior (Tadesse et al., 2018). User habits can significantly affect user behavior (Fakhoury \& Aubert, 2017). People who use technology and systems have a greater ability to adopt emerging technologies even before using technology (Chao, 2019). However, the findings of some research have not found significant behavioral intention. User habits have four indicators developed by Venkatesh et al. (2012): (1) natural - describes the use of OLP technology as a natural thing; (2) habits - explain about the use of OLP technology as a habit; (3) must explain the purpose of OLP technology - as a must; and (4) describes addiction in the use of OLP technology (Figure 1).

H2: User habits have a significant influence on behavioral intentions to use online learning.

\subsection{Behavioral Intentions}

Behavioral intention is a variable that refers to a person's level of intention to use technology (Budu et al., 2018; Venkatesh et al., 2012). The intended behavior is closely related to the actual behavior, and it has diagnostic value. Thus, behavioral intentions are important indicators for management to understand whether customers would remain with or defect from the company. Relationship quality also affects experience and behavior intentions significantly (Tran, 2020). The results of previous studies indicate that the frequency of technology use reduces the impact of behavioral intentions on future technology use (Al-Rahmi et al., 2019). The behavioral intention has three indicators developed by Venkatesh et al. (2012): (1) intention - explaining the plan to continue using OLP technology in the future; (2) habits - tell about the use of OLP technology in daily life; and (3) usage interests - explains the interest in continuing to use OLP technology as often as possible.

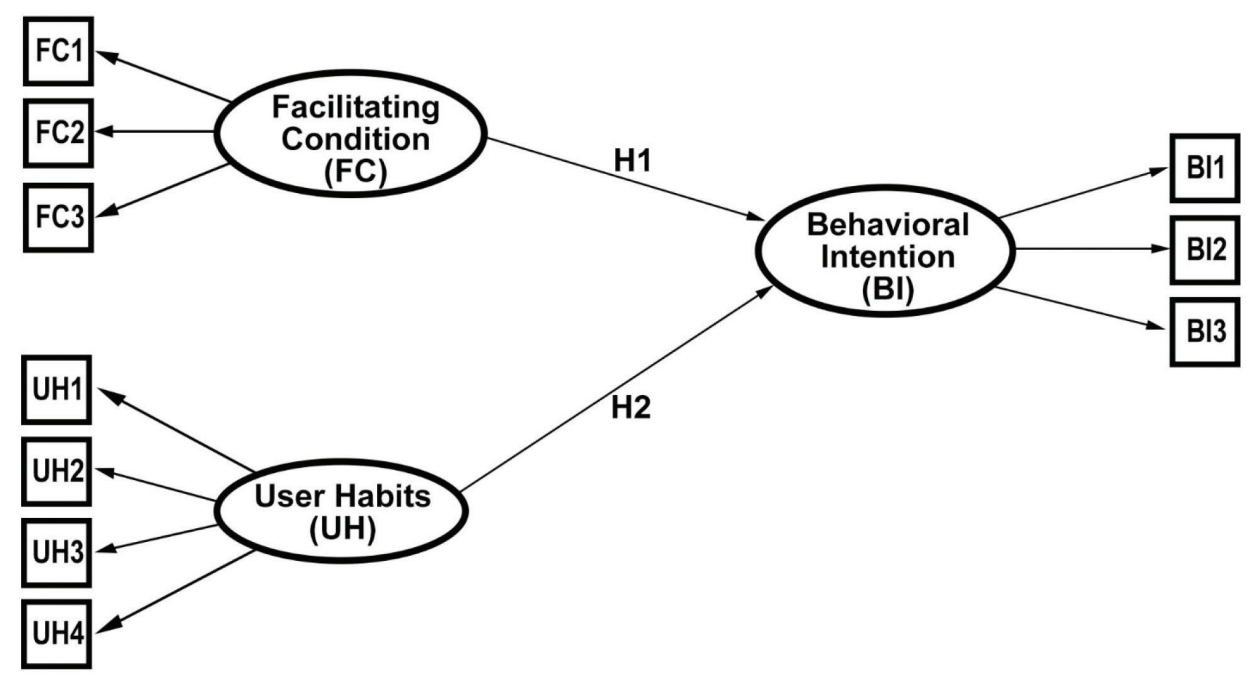

Figure 1: Conceptual Framework 


\section{Methods}

This study aimed to examine the causal effect variable facilitating conditions and user habits on behavioral intentions in the Indonesian OLP. The objective of this study is to clarity the effect between variables built on a model equation based on relevant concepts (explanatory research). The primary data was collected from November 2019 to January 2020 using an online Google Forms questionnaire, which was distributed via various social media such as Instagram, Facebook, and WhatsApp groups. The demographic analysis conducted in this study was categorized based on gender, status, age, education, domicile, occupation, income, usage experience, and frequency of use of OLP technology.

The data collection involves a combination of methods to support the reality behind the quantitative analysis and give a substantial explanation. The researchers applied a Likert scale to measure opinions, behavior, and the respondents' perceptions. Analysis of relationship patterns from this study includes variables aimed to determine the effect of dependent and independent variables by using path model analysis. The dependent variables in this study were facilitating condition and user habits, while the independent variable was the behavioral intention. The validity test shows each item $\mathrm{r}$-arithmetic $>0.30$, and the reliability test results show each item with Cronbach's Alpha value $\geq 0.5$. The dependent variable has a significant impact on the independent variable, whether the $\mathrm{p}$-value $<0.05$.

\section{Results and Discussion}

Two hundred fifty-four respondents completed the questionnaire over ten weeks through online and offline distribution. One hundred three respondents filled out the survey online, and 151 respondents filled out the questionnaire offline. Then, the questionnaire was filtered so that only those using OLP technology (227 respondents) were included in the data. The questionnaire filled out by the respondent needs to be assessed whether the survey was appropriate for use in the next research processes. After checking the 227 questionnaires, two questionnaires were considered inappropriate due to the tendency to fill in all neutral or agree with all questions on the survey. Thus, the questionnaire data that can process for this study amounted to 225 questionnaires (Table 1). The results showed that 154 respondents $(68 \%)$ were women, and 71 respondents $(32 \%)$ were men.

Most of the respondents, 171 respondents (76\%), were unmarried, they were still pursuing an education level, and 125 respondents $(56 \%)$ were less than 23 years old. Most of the respondents, 114 respondents $(51 \%)$, had high school education or equivalent. 188 respondents $(84 \%)$ lived in East Java, One hundred ten respondents (48.9\%) were students, and most of the respondents, namely, 125 respondents (56\%), have an income less than IDR2,500,000. Based on the results of data analysis, 110 respondents have used OLP technology for 12 months (49\%), and the majority of respondents, namely, 98 people (43\%), use OLP technology more than 12 times a year. In conclusion, the results of data analysis regarding the characteristics of respondents indicate that the level of acceptance of OLP technology is still low, less than $50 \%$.

The data analysis in this study used Partial Least Square-Structural Equation Modeling. Evaluation of the structural model and the overall model of this study uses the R-square value to test the relationship between latent independent variables and latent dependent variables. These results indicated that they have a substantial effect with an R-square value of 0.512 , which means that the model created in this study can explain $51.20 \%$ of all the variables analyzed. This model explains other variables outside of facilitating conditions and user habits by $51.20 \%$ and the remaining $48.80 \%$. This model showed that the R-square value obtained from this research model is considered to form a good model. The higher the value of R-square, the better the model. The construct validity test was discriminant validity. This research instrument was considered valid since the AVE value was more significant than 0.5 (AVE> 0.5). Overall, research instruments for facilitating conditions indicators, user habits, and behavioral intention were valid. The reliability test of the research instrument conducted was Cronbach's Alpha analysis, with alpha $>0.60$, so the research instrument was considered reliable. Overall, the indicator facilitating conditions, user habits, and behavioral intention research instruments were reliable in Table 2.

Based on the analysis of data processing facility condition variables (Table 2), the indicator of knowledge related to OLP technology had the largest outer loading of 0.849 . It was significant at $\alpha=5 \%$ (t-statistics $=23,525)$. This indicator is most dominant in reflecting facilitating conditions. Meanwhile, the indicator of the resources needed to use OLP technology had the smallest outer loading, which was positive 0.821 and was significant at $\alpha=5 \%$ (t-statistic $=22.001)$. This indicator was less dominant in reflecting the facilitating conditions variable.

Based on the results of testing the user habits variable, it shows that the use of OLP technology had become a habit is the most important indicator to reflect the user habit variable with outer loading 0.885 and is significant at $\alpha=5 \%$ (t-statistic $=44,453)$. However, indicators of user addiction to use OLP technology had the smallest outer loading of 0.815 and are significant at the t-statistic of 33,354. The most influential factor in user habits was the use of OLP technology, which had become a daily habit. Matters relating to addiction in the use of OLP technology need to get attention so that the adoption of OLP technology could run optimally. 
Table 1: Respondent Demographics

\begin{tabular}{|c|c|c|c|}
\hline \multicolumn{2}{|c|}{ Respondents Profile } & \multirow{2}{*}{$\frac{\text { Frequency }}{71}$} & \multirow{2}{*}{$\begin{array}{c}\text { Percentage (\%) } \\
32 \%\end{array}$} \\
\hline Gender & Men & & \\
\hline & Woman & 154 & $68 \%$ \\
\hline \multirow[t]{2}{*}{ Status } & Single & 171 & $76 \%$ \\
\hline & Married & 54 & $24 \%$ \\
\hline \multirow{3}{*}{ Age } & $<23$ Years & 125 & $56 \%$ \\
\hline & 23-38 years & 91 & $40 \%$ \\
\hline & 39-54 Years & 9 & $4 \%$ \\
\hline \multirow{4}{*}{ Education } & SMA / equivalent & 114 & $51 \%$ \\
\hline & D1 / D2 / D3 & 19 & $8 \%$ \\
\hline & S1 / D4 & 56 & $25 \%$ \\
\hline & S2 / S3 & 36 & $16 \%$ \\
\hline \multirow{6}{*}{ Domicile } & Jakarta & 12 & $5 \%$ \\
\hline & West Java & 5 & $2 \%$ \\
\hline & Central Java & 8 & $3 \%$ \\
\hline & Yogyakarta & 4 & $2 \%$ \\
\hline & East Java & 188 & $84 \%$ \\
\hline & Others & 8 & $4 \%$ \\
\hline \multirow{8}{*}{ Profession } & Not Yet / Not Working & 2 & $0.9 \%$ \\
\hline & Student / Student & 110 & $48.9 \%$ \\
\hline & entrepreneur & 11 & $4.9 \%$ \\
\hline & Health workers & 31 & $13.8 \%$ \\
\hline & PTN / PTS lecturers & 25 & $11.1 \%$ \\
\hline & ASN / PNS & 11 & $4.9 \%$ \\
\hline & General employees & 27 & $12 \%$ \\
\hline & Others & 8 & $3.6 \%$ \\
\hline \multirow{5}{*}{ Income } & $<\mathrm{Rp} 2.500 .000$ & 125 & $56 \%$ \\
\hline & Rp. 2.500.000-Rp. 5.000.000 & 34 & $15 \%$ \\
\hline & Rp. 5.000.001-Rp. 7.500.000 & 34 & $15 \%$ \\
\hline & Rp.7.500.001-Rp.10.000.000 & 13 & $6 \%$ \\
\hline & > Rp. 10.000 .000 & 19 & $8 \%$ \\
\hline \multirow{5}{*}{ Experience of Use } & $<1$ month & 27 & $12.0 \%$ \\
\hline & 1-3 months & 40 & $17.8 \%$ \\
\hline & 4-6 Months & 31 & $13.8 \%$ \\
\hline & 7-12 Months & 17 & $7.6 \%$ \\
\hline & $>12$ Months & 110 & $48.9 \%$ \\
\hline \multirow{5}{*}{ Frequency of use } & $<3$ times per year & 40 & $18 \%$ \\
\hline & 4-6 times per year & 42 & $19 \%$ \\
\hline & 7-9 times per year & 24 & $11 \%$ \\
\hline & 10-12 times per year & 21 & $9 \%$ \\
\hline & $>12$ times per year & 98 & $43 \%$ \\
\hline
\end{tabular}


Table 2: Construct Reliability and Validity

\begin{tabular}{|l|c|c|c|c|}
\hline & Cronbach's Alpha & rho_A & Composite Reliability & AVE \\
\hline Behavioral Intention & 0.869 & 0.875 & 0.920 & 0.792 \\
\hline Faciliting Condition & 0.789 & 0.799 & 0.876 & 0.701 \\
\hline User Habit & 0.868 & 0.871 & 0.910 & 0.717 \\
\hline
\end{tabular}

Table 3: Outer Loading

\begin{tabular}{|l|c|c|c|c|c|}
\hline & Original Sample & Sample Mean (M) & Standard Deviation & T Statistics & P Values \\
\hline $\mathrm{BI} 1 \leftarrow \mathrm{BI}$ & 0.875 & 0.875 & 0.020 & 42.962 & 0.000 \\
\hline $\mathrm{BI} 2 \leftarrow \mathrm{BI}$ & 0.913 & 0.913 & 0.013 & 67.894 & 0.000 \\
\hline $\mathrm{BI} 3 \leftarrow \mathrm{BI}$ & 0.882 & 0.882 & 0.019 & 45.885 & 0.000 \\
\hline $\mathrm{FC} 1 \leftarrow \mathrm{FC}$ & 0.821 & 0.817 & 0.037 & 22.001 & 0.000 \\
\hline $\mathrm{FC} 2 \leftarrow \mathrm{FC}$ & 0.849 & 0.846 & 0.036 & 23.525 & 0.000 \\
\hline $\mathrm{FC} 3 \leftarrow \mathrm{FC}$ & 0.842 & 0.844 & 0.024 & 35.052 & 0.000 \\
\hline $\mathrm{UH} 1 \leftarrow \mathrm{UH}$ & 0.830 & 0.828 & 0.031 & 26.343 & 0.000 \\
\hline $\mathrm{UH} 2 \leftarrow \mathrm{UH}$ & 0.885 & 0.883 & 0.020 & 44.453 & 0.000 \\
\hline $\mathrm{UH} 3 \leftarrow \mathrm{UH}$ & 0.856 & 0.856 & 0.027 & 31.537 & 0.000 \\
\hline $\mathrm{UH} 4 \leftarrow \mathrm{UH}$ & 0.815 & 0.814 & 0.024 & 33.354 & 0.000 \\
\hline
\end{tabular}

Based on the results of testing the behavioral intention variable, it shows that the indicator of OLP usage habits in daily life was the most important indicator to reflect the behavioral intention variable with outer loading 0.913 and is significant at $\alpha=5 \%$ (t-statistic $=67,894)$. However, the indicator of the user's intention to continue to use OLP technology in the future had the smallest outer loading of 0.875 and a significant t-statistic of 42.962 . This indicator of user intentions is less dominant, reflecting behavioral intention variables. The behavioral intention was a variable that stated a person's level of intention to use OLP technology. The experience could be a moderating effect of behavioral intention to use behavior.

The effect of facilitating conditions variable on behavioral intention was significant. The path coefficient of this study was 0.258 and t-statistics of 4.207 (Table 3). The facilitating conditions had a significant effect on behavioral intention. The impact of user habits variable on behavioral intention was significant. The path coefficient of this study was 0.573 and t-statistics of 10.366 (Table 3). User habits had a significant effect on behavioral intention. The results of the analysis for construct facilitating conditions were in line with the results of previous studies on online learning, which state that there is a significant relationship between facilitating conditions and behavioral intention (Razak et al., 2017; Masadeh et al., 2016; Raman \& Don, 2013). Factors such as lack of assistance and timely support, incomplete information, and limited resources can prevent individuals from accepting web-based technology (Masadeh et al., 2016).

Previous studies have suggested that older consumers tend to prioritize the availability of adequate support (Gupta et al., 2016; Witten et al., 2011). On the other hand, previous studies stated that men made more efforts to overcome various obstacles and difficulties in pursuing their goals. At the same time, women tend to focus more on the amount of effort involved and the process to achieve their goals. In other words, men tend not to be dependent on facilitating conditions when considering the use of new technology (Hennig-Thurau et al., 2002; Santoso et al., 2019; Chan et al., 2010). Previous studies stated that more experience could lead to greater familiarity with technology and better knowledge to facilitate learning, thereby reducing dependence on external support (Broadbent \& Poon, 2015; Gallego \& Topaloglu, 2019). Users with little technological experience are more dependent on facilitating conditions (Suryanto et al., 2016). Age, gender, and experience of moderation did not have a significant effect on the condition of facilitation on the behavioral intention from the perception of the demo-graphic differences of respondents in this study. The majority of respondents came from the educational community, especially students. Internet support facilities using laptops and smartphones in the use of OLP technology have been widely available at low prices. Today's students can easily reach Internet facilities, anywhere and anytime. 
Table 4: Path Coefficient

\begin{tabular}{|l|c|c|c|c|c|}
\hline & $\begin{array}{c}\text { Original } \\
\text { Sample }\end{array}$ & $\begin{array}{c}\text { Sample } \\
\text { Mean (M) }\end{array}$ & $\begin{array}{c}\text { Standard } \\
\text { Deviation }\end{array}$ & $\begin{array}{c}\mathbf{T} \\
\text { Statistics }\end{array}$ & $\begin{array}{c}\mathbf{P} \\
\text { Values }\end{array}$ \\
\hline Facilitating Condition $\rightarrow$ Behavioral Intention & 0.258 & 0.258 & 0.061 & 4.207 & 0.000 \\
\hline User habits $\rightarrow$ Behavioral Intention & 0.573 & 0.574 & 0.055 & 10.366 & 0.000 \\
\hline
\end{tabular}

User habits described the level to which individuals tend to perform behaviors automatically be-cause they have learned them before (Gallego \& Topaloglu, 2019; Venkatesh et al., 2012). Previous studies showed that age, gender, and experience had no significant effect in moderating the influence of user habits on behavioral intention. The results of the analysis for the construct of user habits are similar with the results of previous studies on online learning (see Table 4), which stated that there is a significant relationship between user habits and behavioral intention (Masadeh et al., 2016; Mehta et al., 2019). Habits played an essential role in the use of technology, especially in diverse and fluid situations (Venkatesh et al., 2012).

\section{Conclusion}

Based on the results of the analysis and discussion of the effect of facilitating conditions on behavioral intention, the provider needs to pay attention to factors related to facilitating conditions to gain more OLP users. This impact is primarily associated with the availability of the resources required to use OLP technology. The availability of these resources includes the availability of supporting infrastructures such as Internet access, easy access to use mobile devices, and file sizes that affect access speed. The opportunity to increase the number of OLP technology users in the future is wide opened. Providers also need to pay attention to factors related to user habits, especially about various things that make OLP technology an ordinary matter. The factors related to user habits are closely related to the general condition of society in Indonesia, where people is still relatively unfamiliar with new technology. There needs to be an introduction and familiarization of OLP technology usage.

The formulation of research problems, the creation of a research model framework, the collection and analysis of data, and the documentation of research results in a limited time lead to limitations in the scope and size of this study. Therefore, future research can continue on this path by using different research models, adding more samples, adding other research variables such as perceived risk and learning value, and adopting other technology platforms.

\section{References}

Ain, N., Kaur, K., \& Waheed, M. (2016). The influence of learning value on learning management system use.
Information Development, 32(5), 1306-1321. https://doi. org/10.1177/0266666915597546

Al-Husban, N. A., \& Alshorman, S. M. (2020). Perceptions of syrian student refugees towards blended learning: Implications for higher education institutions. International Journal of Emerging Technologies in Learning, 15(1), 45-60. https://doi. org/10.3991/ijet.v15i01.11431

Al-Rahmi, W. M., Yahaya, N., Aldraiweesh, A. A., Alamri, M. M., Aljarboa, N. A., Alturki, U., \& Aljeraiwi, A. A. (2019). Integrating Technology Acceptance Model with Innovation Diffusion Theory: An Empirical Investigation on Students' Intention to Use E-Learning Systems. IEEE Access, 7, 2679726809. https://doi.org/10.1109/ACCESS.2019.2899368

Ambarwati, R., Handiwibowo, G., \& Febriansah, R. (2020). Impact of Outbound Training in Organization Mission Statement: A Managerial Implication, Proceedings of the 1st International Conference on Business, Law And Pedagogy (pp. 1-10), ICBLP 2019, 13-15 February 2019, Sidoarjo, Indonesia. https://doi. org/10.4108/eai.13-2-2019.2286081

Broadbent, J., \& Poon, W. L. (2015). Self-regulated learning strategies \& academic achievement in online higher education learning environments: A systematic review. Internet and Higher Education, 27, 1-13. https://doi.org/10.1016/j. iheduc.2015.04.007

Budu, K. W. A., Yinping, M., \& Mireku, K. K. (2018). Investigating The Effect of Behavioral Intention on E-learning Systems Usage: Empirical Study on Tertiary Education Institutions in Ghana. Mediterranean Journal of Social Sciences, 9(3), 201216. https://doi.org/10.2478/mjss-2018-0062

Chan, F. K. Y., Thong, J. Y. L., Venkatesh, V., Brown, S. A., Hu, P. J. H., \& Tam, K. Y. (2010). Modeling citizen satisfaction with mandatory adoption of an E-Government technology. Journal of the Association for Information Systems, 11(10), 519-549. https://aisel.aisnet.org/jais/vol11/iss10/2

Chao, C. M. (2019). Factors determining the behavioral intention to use mobile learning: An application and extension of the UTAUT model. Frontiers in Psychology, 10(1652), 1-14. https://doi.org/10.3389/fpsyg.2019.01652

Choi, C., Kim, C., \& Kim, C. (2019). Towards Sustainable Environmental Policy and Management in the Fourth Industrial Revolution: Evidence from Big Data Analytics. Journal of Asian Finance, Economics and Business, 6(3), 185-192. https:// doi.org/10.13106/jafeb.2019.vol6.no3.185

El-Masri, M., \& Tarhini, A. (2017). Factors affecting the adoption of e-learning systems in Qatar and USA: Extending the Unified Theory of Acceptance and Use of Technology 2 (UTAUT2). 
Educational Technology Research and Development, 65(3), 743-763. https://doi.org/10.1007/s11423-016-9508-8

El Ouirdi, M., El Ouirdi, A., Segers, J., \& Pais, I. (2016). Technology adoption in employee recruitment: The case of social media in Central and Eastern Europe. Computers in Human Behavior, 57, 240-249. https://doi.org/10.1016/j.chb.2015.12.043

Engle, D., Mankoff, C., \& Carbrey, J. M. (2015). Coursera's Introductory Human Physiology Course: Factors that Characterize Successful Completion of a MOOC. International Review of Research in Open and Distance Learning, 16(2), 46-68. https://doi.org/10.19173/irrodl.v16i2.2010

Fakhoury, R., \& Aubert, B. (2017). The impact of initial learning experience on digital services usage diffusion: A field study of e-services in Lebanon. International Journal of Information Management, 37(4), 284-296. https://doi.org/10.1016/j. ijinfomgt.2017.03.004

Gallego, G., \& Topaloglu, H. (2019). Revenue Management and Pricing Analytics, Online Learning. In International Series in Operations Research and Management Science, 279, 275-289. https://doi.org/10.1007/978-1-4939-9606-3_10

Gupta, K. P., Singh, S., \& Bhaskar, P. (2016). Citizen adoption of e-government: A literature review and conceptual framework. Electronic Government. 12(2). https://doi.org/10.1504/ EG.2016.076134

Halili, S. H., \& Sulaiman, H. (2019). Factors influencing the rural students' acceptance of using ICT for educational purposes. Kasetsart Journal of Social Sciences, 2018, 1-6. https://doi. org/10.1016/j.kjss.2017.12.022

Hennig-Thurau, T., Gwinner, K. P., \& Gremler, D. D. (2002). Understanding Relationship Marketing Outcomes. Journal of Service Research, 4(3), 230-247. https://doi. org/10.1177/1094670502004003006

Jalil, H. A., Ma'rof, A. M., \& Omar, R. (2019). Attitude and behavioral intention to develop and use MOOCs among academics. International Journal of Emerging Technologies in Learning, 14(24), 31-41. https://doi.org/10.3991/ijet. v14i24.12105

Kamaghe, J., Luhanga, E., \& Kisangiri, M. (2020). The challenges of adopting M-learning assistive technologies for visually impaired learners in higher learning institution in Tanzania. International Journal of Emerging Technologies in Learning, 15(1), 140-151. https://doi.org/10.3991/ijet.v15i01.11453

Lee, J. W. (2017). Critical Factors Affecting Consumer Acceptance of Online Health Communication: An Application of Service Quality Models. Journal of Asian Finance, Economics and Business, 4(3), 85-94. https://doi.org/10.13106/jafeb.2017. vol4.no3.85

Lee, J. W. (2020). Big Data Strategies for Government, Society and Policy-Making. Journal of Asian Finance, Economics and Business, 7(7), 475-487. https://doi.org/10.13106/jafeb.2020. vol7.no7.475

Lieharyani, D. C. U., Hari Ginardi, R. V., Ambarwati, R., \& Multazam, M. T. (2019). Assessment for good university governance in higher education focus on align strategy business with it at big data era. Journal of Physics: Conference Series, Volume 1175, 1st International Conference on Advance and Scientific Innovation, 23-24 April 2018, Medan, Indonesia. https://doi.org/10.1088/1742-6596/1175/1/012204

Liu, L., Miguel Cruz, A., Rios Rincon, A., Buttar, V., Ranson, Q., \& Goertzen, D. (2015). What factors determine therapists' acceptance of new technologies for rehabilitation-a study using the Unified Theory of Acceptance and Use of Technology (UTAUT). Disability and Rehabilitation, 37(5), 447-455. https://doi.org/10.3109/09638288.2014.923529

Masadeh, R., Tarhini, A., Mohammed, A. B., \& Maqableh, M. (2016). Modeling Factors Affecting Student's Usage Behaviour of E-Learning Systems in Lebanon. International Journal of Business and Management, 11(2), 299-312. https://doi.org $/ 10.5539 /$ ijbm.v11n2p299

Mehta, A., Morris, N. P., Swinnerton, B., \& Homer, M. (2019). The Influence of Values on E-learning Adoption. Computers \& Education, 141, 103617. https://doi.org/10.1016/j. compedu.2019.103617

Muafi, M. (2020). A Nexus among Strategic Orientation, Social Network, Knowledge Sharing, Organizational Innovation, and MSMEs Performance. Journal of Asian Finance, Economics and Business, 7(6), 327-338. https://doi.org/10.13106/ jafeb.2020.vol7.no6.327

Muniasamy, A., \& Alasiry, A. (2020). Deep learning: The impact on future eLearning. International Journal of Emerging Technologies in Learning, 15(1), 188-199. https://doi. org/10.3991/IJET.V15I01.11435

Neslin, S. A., \& Shankar, V. (2009). Key Issues in Multichannel Customer Management: Current Knowledge and Future Directions. Journal of Interactive Marketing, 23(1), 70-81. https://doi.org/10.1016/j.intmar.2008.10.005

Nguyen, T. (2015). The Effectiveness of Online Learning: Beyond No Significant Difference and Future Horizons. MERLOT Journal of Online Learning and Teaching, 11(2), 309-319. https://jolt.merlot.org/Vol11no2/Nguyen_0615.pdf

Niemi, H., \& Jia, J. (Eds.). (2017). New Ways to Teach and Learn in China and Finland. Bern, Switzerland: Peter Lang D. Retrieved Aug 26, 2020, from https:/www.peterlang.com/ view/title/19509

Panigrahi, R., Srivastava, P. R., \& Sharma, D. (2018). Online learning: Adoption, continuance, and learning outcome. A review of literature. International Journal of Information Management, 43, 1-14. https://doi.org/10.1016/j.ijinfomgt.2018.05.005

Paul, K. J., Musa, M., \& A Nansubuga, A. K. (2015). Facilitating Condition for E-learning Adoption-Case of Ugandan Universities. Journal of Communication and Computer, 12(2015), 244-249. https://doi.org/10.17265/1548-7709/2015. 05.004

Perrin, X., Colas, F., Pradalier, C., Siegwart, R., Chavarriaga, R., \& Millán, J. D. R. (2011). Learning user habits for semiautonomous navigation using low throughput interfaces. In: Conference Proceedings - IEEE International Conference on 
Systems, Man and Cybernetics, Anchorage, AK. https://doi. org/10.1109/ICSMC.2011.6083633

Pimmer, C., Brühlmann, F., Odetola, T. D., Oluwasola, D. O., Dipeolu, O., \& Ajuwon, A. J. (2019). Facilitating professional mobile learning communities with instant messaging. Computers and Education, 128, 102-112. https://doi. org/10.1016/j.compedu.2018.09.005

Raman, A., \& Don, Y. (2013). Preservice Teachers' Acceptance of Learning Management Software: An Application of the UTAUT 2 Model. International Education Studies, 6(7), 157164. https://doi.org/10.5539/ies.v6n7p157

Razak, F. Z. B. A., Bakar, A. A., \& Abdullah, W. S. W. (2017). How perceived effort expectancy and social influence affects continuance of intention to use e-government. A study of a Malaysian government service. Electronic Government, an International Journal, 13(1). https://doi.org/10.1504/ eg.2017.10004264

Santoso, H. B., Desprianto, D. A., Nurrohmah, I., Nursalamah, R. K., \& Putra, P. O. H. (2019). Customer journey construction of the Indonesian open-education resources platform. International Journal of Emerging Technologies in Learning, 14(24), 18-30. https://doi.org/10.3991/ijet.v14i24.12045

Suryanto, T. L. M., Setyohadi, D. B., \& Faroqi, A. (2016). Analysis of the Effect of Information System Quality to Intention to Reuse of Employee Management Information System (Simpeg) Based on Information Systems Success Model. In: Proceeding of the Third Bali International Seminar on Science and Technology (pp. 1-6). https://doi.org/10.1051/matecconf/ 20165803001
Swan, K., Shen, J., \& Hiltz, S. R. (2019). Assessment And Collaboration In Online Learning. Online Learning Journal, 45-62. https://doi.org/10.24059/olj.v10i1.1770

Tadesse, M. M., Lin, H., Xu, B., \& Yang, L. (2018). Personality Predictions Based on User Behavior on the Facebook Social Media Platform. IEEE Access, 6, 61959-61969. https://doi. org/10.1109/ACCESS.2018.2876502

Tran, V. D. (2020). Assessing the Effects of Service Quality, Experience Value, Relationship Quality on Behavioral Intentions. Journal of Asian Finance, Economics and Business, 7(3), 167-175. https://doi.org/10.13106/jafeb.2020.vol7.no3.167

Venkatesh, V., Morris, M. G., \& Ackerman, P. L. (2005). Gender and Age Differences in Employee Decisions About New Technology: An Extension to the Theory of Planned Behavior. IEEE Transactions on Engineering Management, 52(1), 69-84. https://doi.org/10.1109/TEM.2004.839967

Venkatesh, V., Thong, J. Y. L., \& Xu, X. (2012). Consumer Acceptance and Use of Information Technology: Extending The Unified Theory of Acceptance and Use of Technology. MIS Quarterly, 157-178. https://doi.org/10.2307/41410412

Witten, I. H., Frank, E., \& Hall, M. A., (2011). Data Mining: Practical Machine Learning Tools and Techniques. Amsterdam, the Netherlands: Elsevier. https://doi.org/10.1016/c2009-019715-5

Xiang, Y., Alahi, A., \& Savarese, S. (2015). Learning to track: Online multi-object tracking by decision making. In: Proceedings of the IEEE International Conference on Computer Vision, Santiago, Chile. https://doi.org/10.1109/ICCV.2015.534 